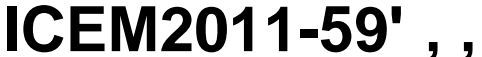

\section{HIGH WASTE LOADING GLASS FORMULATIONS FOR HANFORD HIGH-ALUMINUM HIGH- LEVEL WASTE STREAMS}

\author{
Albert A. Kruger, Glass Scientist \\ DOE-WTP Project Office Engineering Division \\ US Department of Energy \\ Richland, Washington USA
}

\begin{abstract}
The current estimates and glass formulation efforts have been conservative in terms of achievable waste loadings. These formulations have been specified to ensure that the glasses are homogenous, contain essentially no crystalline phases, are processable in joule-heated, ceramic-lined melters and meet WTP Contract terms. The WTP's overall mission will require the immobilization of tank waste compositions that are dominated by mixtures of aluminum ( $\mathrm{Al})$, chromium $(\mathrm{Cr})$, bismuth $(\mathrm{Bi})$, iron $(\mathrm{Fe})$, phosphorous $(\mathrm{P})$, zirconium $(\mathrm{Zr})$, and sulfur ( $\mathrm{S}$ ) compounds as waste-limiting components. Glass compositions for these waste mixtures have been developed based upon previous experience and current glass property models. Recently, DOE has initiated a testing program to develop and characterize HLW glasses with higher waste loadings. Results of this work have demonstrated the feasibility of increases in waste loading from about $25 \mathrm{wt} \%$ to $33-50 \mathrm{wt} \%$ (based on oxide loading) in the glass depending on the waste stream. It is expected that these higher waste loading glasses will reduce the HLW canister production requirement by about $25 \%$ or more.
\end{abstract}

\section{INTRODUCTION}

Refractory components, such as crystalline alumina (corundum) or zirconia (baddeleyite) slow down the melting of glass batches in continuous melters. This effect can be considerable. Gibbsite and boehmite are common minerals found in high-level wastes.

Laboratory examination revealed that the batches with corundum produced copious primary foam whereas the batches with gibbsite did not. Primary foam is a term coined by Gerrard and Smith for batch expansion caused by the evolution of batch- reaction gases, such as $\mathrm{CO}_{2}$, after enough glass-forming melt was produced in the batch to close the open pores. Secondary foam is generally a term reserved for foam created in molten glass from fining-reaction gases. In high-level waste glass melts, secondary foam results from oxidation-reduction reactions, mainly involving ferric oxide.

Foam within or under the batch blanket or the cold cap may hinder the heat transfer from the melt below and thus slow down melting. The aim of this paper is to present our laboratory studies undertaken to understand the recent observations in the pilot-scale melter where batches prepared with gibbsite $\left[\mathrm{Al}(\mathrm{OH})_{3}\right]$ and boehmite $[\mathrm{AlO}(\mathrm{OH})]$ melted substantially faster than the batch prepared with corundum $\left(\mathrm{Al}_{2} \mathrm{O}_{3}\right)$.

In view of the importance of aluminum limited waste streams at Hanford (and also Savannah River), the ability to achieve high waste loadings without adversely impacting melt rates has the potential for enormous cost savings from reductions in canister count and the potential for schedule acceleration. Consequently, the potential return on the investment made in the development of these enhancements is extremely favorable.

\section{NOMENCLATURE}

DOE US Department of Energy

DM-10 DuraMelter-10 (0.02 $\mathrm{m}^{2}$ melt surface area)

DM-100 DuraMelter-100 $\left(0.11 \mathrm{~m}^{2}\right.$ melt surface area $)$

DM-1200 DuraMelter-1200 (1.2 $\mathrm{m}^{2}$ melt surface area)

WTP High Level Waste Melter $3.75 \mathrm{~m}^{2}$ melt surface area

ILAW Immobilized Low-Activity Waste

IHLW Immobilized High-Level Waste

MT Metric Tonnes 
ORP

PCT

TCLP

WTP

The principal objectives of the work presented here were to evaluate further enhancements to waste loadings and processing rate, the effect of boehmite as an aluminum source in the waste simulant, and the effect of using low activity waste (LAW) streams as a source of sodium in place of chemical additives. Also evaluated were the effects of the type of reductant used, glass temperature, and waste solids content. This was accomplished through a combination of crucible-scale tests, confirmation tests on the DM100 melter system, and demonstration at pilot scale (DM1200). The DM100-BL unit was selected for these tests since it was used previously with the HLW waste streams evaluated in this study, tests on HLW glass compositions that were used to support subsequent tests on the HLW Pilot Melter, to assess the volatility of cesium and technetium during the vitrification of an HLW AZ-102 composition, to evaluate glass composition and properties on the production rate of a high iron HLW waste composition and to evaluate the effects of spinel and chromium oxide particles on WTP HLW melter operations and potential impacts on melter life. The same melter was selected for the present tests in order to maintain comparisons between the previously collected data. The tests provided information on melter processing characteristics and off-gas data, including formation of secondary phases and partitioning. Once the glass formulation development work was complete, the data were reviewed and a decision was made on the formulation advanced to DM100-BL for testing. A similar review process after DM100 tests gave direction for the feed composition used for testing on the DM1200.

The principal objectives of this work were to:

(1) Develop and test an improved aluminum-limited glass with $\mathrm{Al}_{2} \mathrm{O}_{3}$ concentration above $24 \mathrm{wt} \%$ and waste loading of greater than $45 \%$, and high processing rate.

(2) Assess the effect of using LAW waste as a sodium source with an aluminum-limited HLW waste stream.

(3) Determine the effect on glass production rates of boehmite as a waste aluminum source while processing an aluminum-limited HLW waste stream.

(4) Determine the effect on glass production rates of decreased feed solids content as a result of the incorporation of LAW waste as an additive source with an aluminum-limited HLW waste stream.
(5) Determine the effect on glass production rates of reductant type used as a result of the incorporation of LAW waste as an additive source with an aluminum-limited HLW waste stream.

(6) Test product glasses for properties including viscosity, electrical conductivity, crystallinity, gross glass phase separation, and chemical durability (TCLP and PCT).

(7) Determine the effect of modest increase in melter operating temperature on production rate and melter emissions for six different feed compositions.

Glass composition development was based on one of the HLW waste compositions specified by ORP that has a high concentration of aluminum. Small-scale tests were used to provide an initial screening of various glass formulations with respect to melt rates; more definitive screening was provided by the subsequent DM100 tests. Glass properties evaluated included: viscosity, electrical conductivity, crystallinity, glass phase separation and response on the 7-day Product Consistency Test (ASTM-1285). Glass property limits were based upon the reference properties for the WTP HLW melter. However, the WTP crystallinity limit $\left(<1 \mathrm{vol} \%\right.$ at $\left.950^{\circ} \mathrm{C}\right)$ was relaxed slightly as a waste loading constraint for the crucible melts.

\section{ACKNOWLEDGMENTS}

The author is grateful to the U.S. Department of Energy Federal Project Office for the Hanford Tank Waste Treatment and Immobilization Plant for financial support. To Professor Pavel Hrma for his unwavering encouragement and invaluable participation in demonstrating the flexibility of the joule-heated ceramic-lined melter combined with formulations of borosilicate glasses. Additionally, for his lead role in providing us with the fundamental understanding of melt dynamics and cold-cap chemistries. Finally, to Professor Ian Pegg and the staff of the Vitreous State Laboratory of the Catholic University of America for their execution of all the work on scaling and pilot-scale processing.

\section{REFERENCES}

Matlack, K. S., Gan, H, Chaudhuri, M, Kot, W., Gong, W. Bardakci, T., Pegg, I. L., Joseph, I. and Kruger A. A., DM100 and DM1200 Melter Testing with High Waste Loading Glass Formulations for Hanford High Aluminum HLW Streams, US DOE ORP-47690, 9 September, 2010. 